\title{
Systemic intermediaries and the transition toward forest-based bioeconomy in the North
}

\author{
Antje Klitkou ${ }^{1}$ (D) S Suyash Jolly ${ }^{2}$ (D) - Nina Suvinen ${ }^{3}$
}

Accepted: 21 October 2020/Published online: 04 November 2020

(C) The Author(s) 2020

\begin{abstract}
The activities of cluster initiatives operating as systemic intermediaries and supporting networking activities have been discussed in prior studies. We integrate insights from the cluster theory and the literature on sustainability transitions to study the activities of clusters acting as systemic intermediaries in the different phases of the development of a forest-based bioeconomy, namely (1) predevelopment and exploration; (2) takeoff; (3) acceleration and (4) stabilisation. We study three regional cluster initiatives in three different Nordic regions: forest bioeconomy, Central Finland, Finland; Paper Province, Värmland, Sweden, and Arena Skog, Trøndelag, Norway. The paper highlights that the crises in the forestbased industries in Värmland and Trøndelag were the starting point for forestbased cluster development in these regions, while in Central Finland the development was a part of the general economic restructuring of the Finnish economy during the first phase. In the fourth phase, the discontinuity of developed collaboration structures created opportunities for project-oriented collaboration in the case of Central Finland while in the Värmland and the Trøndelag case, the cluster initiatives have broadened the focus of the cluster but also continued the core activities.
\end{abstract}

Keywords Intermediaries · Bioeconomy · Trøndelag · Värmland $\cdot$ Central Finland · Forest industry

R11: Regional Economic Activity: Growth, Development, Environmental Issues and Changes

Antje Klitkou

antje.klitkou@nifu.no

1 NIFU Nordic Institute for Studies in Innovation, Research and Education, Oslo, Norway

2 Lund University, Lund, Sweden

3 Tampere University, Tampere, Finland 


\section{Introduction}

The European pulp and paper industry has been in crisis due to the decreasing demand for print paper and increased competition from Southeast Asia and Southern America. Pulp and paper mills have focused on incremental innovation and efficiency gains as a strategy to compete (Hansen and Coenen 2017). More forward-looking strategies to overcome this path dependency include forest-based biorefineries producing a broad scope of products, and they have been discussed for Finland (Kangas et al. 2011; Hämäläinen et al. 2011; Näyhä and Pesonen 2014), Sweden (Söderholm and Lundmark 2009; Karltorp and Sandén 2012; Hansen and Coenen 2017; Bauer et al. 2018; Scordato et al. 2018) and Norway (Klitkou et al. 2019; Skog22 - Arbeidsgruppe fiber og bioraffineri 2014; Klitkou 2020).

As the global forest industry is undergoing a major structural change, there is a demand for new value-added products, such as bioplastics, pharmaceuticals, wood products for the construction sector and new materials for the textile and chemical industries. The bioeconomy has gained attention due to the emphasis on the conversion of biological resources and the wastes and side-streams associated with them into value-added products, such as biobased products and bioenergy, to reduce the risk of climate and contribute to local and regional rural economic development (Refsgaard et al. 2018; Bauer et al. 2018). The forest-based bioeconomy encompasses not only primary production and secondary processing industries but also some hybrid industries that exploit both fossil-based and forest-based materials, such as the production of furniture, plastic, pharmaceuticals, chemicals and textiles (Capasso and Klitkou 2020). The forest industry in the Nordic countries has implemented different cluster initiatives to overcome some of the barriers and to develop new collaborations with other industries and research and development providers (Nordisk Ministerråd 2018).

Bioclusters are being promoted in peripheral regions with strong links to forestry, agriculture and the pulp and paper industry (Ayrapetyan and Hermans 2020). Since we are interested in the regional context of the forest-based bioeconomy, we also take into account the literature on the mediating role of cluster initiatives in transition processes (Cooke 2007; Hermans 2018). Cluster initiatives play an important role in creating effective platforms for interaction between firms, universities, research institutes, industry associations, regional governments and civil society to enable better dialogue between the different members (Laur 2015). Prior studies have also indicated that studying bioclusters offers new opportunities to combine insights from the cluster theory and the sustainability transitions literature (Hermans 2018). In this paper, we emphasize the role of cluster initiatives which perform the role of systemic intermediaries (Laur et al. 2012; Hermelin and Rämö 2017). We are interested in understanding the activities of regional bioeconomy clusters (Ayrapetyan and Hermans 2020) acting as systemic intermediaries (Mignon and Kanda 2018). Furthermore, we also focus on the clustering efforts of particular intermediaries which support an industrial transition in the different regions.

While existing evolutionary innovation models have looked at the diffusion of technological knowledge, the concept of dedicated innovation systems includes the radical transformation of existing routines and institutional arrangements. There is a need to overcome the rigid inertia associated with the incumbent fossil fuel-based systems and facilitate bioeconomy development (Pyka 2017). Similarly, the 
sustainability transitions literature has adopted a broader view of socio-technical change and looked at systemic-level changes in production and consumption in key infrastructure sectors, such as agro-food, water, energy and health care (Markard et al. 2012). Prior research on the role of intermediaries has examined how intermediaries facilitate sustainability transitions (Van Lente et al. 2003; Kivimaa 2014; Mignon and Kanda 2018).

In this paper, we use insights from studies on systemic intermediaries within the sustainability transitions literature (Howells 2006; Van Lente et al. 2003, 2020) to discuss the activities of cluster initiatives in three different forest industry Nordic regions: Central Finland (Finland), Värmland (Sweden) and Trøndelag (Norway). We study the ways in which cluster initiatives act as systemic intermediaries to support the industrial transition process. Different regions provide unique institutional conditions for facilitating the role of intermediaries to accelerate sustainability transitions, and thus there is a need to analyse the variations between different regions (Van Boxstael et al. 2020). The main research question of the paper is as follows: Which activities do cluster initiatives acting as systemic intermediaries engage in during the different phases of transition to facilitate the development of a forest-based bioeconomy in the Nordic regions?

The contribution of the paper is that we combine insights from the cluster theory (Menzel and Fornahl 2010) and the literature on systemic intermediaries within the sustainability transitions literature to study emerging Bioeconomy clusters (Hermans 2018; Ayrapetyan and Hermans 2020). We address the recent calls for taking a spatial perspective on the activities of intermediaries (Hodson et al. 2013; Van Boxstael et al. 2020 ) and highlight the variations in the activities of the three cluster initiatives in the four different transition phases: (1) predevelopment and exploration; (2) takeoff; (3) acceleration and (4) stabilisation (Kivimaa et al. 2019b). The paper is structured as follows. In Section 2, we discuss the theoretical background of the study. In Section 3, we elaborate on the research method used for the study. Section 4 discusses the case study. Finally, we discuss and conclude the paper in Section 5 and Section 6 and provide avenues for future research.

\section{Theoretical framework}

\subsection{Cluster initiatives as systemic intermediaries}

Previous studies on systemic intermediaries (Kivimaa 2014; Kivimaa et al. 2019a, b) indicate that intermediaries align the interests of different actors and create a collective vision for change. Systemic intermediaries perform a range of functions, such as creating conditions for learning by doing, using and interacting, network building, brokerage, consensus building and long-term strategy development (Van Veelen 2019; Kanda et al. 2020; Van Lente et al. 2020). A key issue relating to the activities of intermediaries is their survivability and the source and long-term stability of their funding (Kant and Kanda 2019). A few studies have also suggested that the literature on systemic intermediaries has often failed to explain how the activities of intermediaries change over time in response to the changing contextual environment (Kivimaa et al. 2019b; Kant and Kanda 2019; Manders et al. 2020). 
Systemic intermediaries have been studied at different spatial boundaries, including at the city level (e.g. Hodson et al. 2013; Hielkema and Hongisto 2013) and the regional level (e.g. Klerkx and Leeuwis 2009; Hermans 2018; Kanda et al. 2019). At the regional level, Kanda et al. (2019) studied the role of systemic intermediaries in promoting ecoinnovation in regions such as Scania, Sweden, and North-Rhine Westphalia, Germany. Different regions provide unique and varied institutional conditions for intermediaries (Van Boxstael et al. 2020). We study the activities of cluster initiatives acting as systemic intermediaries often in collaboration with other types of actors located in a specific geographic area (Mignon and Kanda 2018).

\subsubsection{Cluster initiatives}

As we are interested in exploring the activities of cluster initiatives, we use insights from the prior literature on cluster development (Menzel and Fornahl 2010; Trippl et al. 2015).Cluster initiatives have been discussed as collaborative actions by different firms, research institutes and research and educational institutes to improve the competitiveness of a cluster by raising awareness and developing new platforms for interaction between them (Ketels and Memedovic 2008). Cluster initiatives are defined as "entities emanating and inspiring surrounding actors for joint activities and collaborations. Furthermore, they are entrepreneurial organizations with an intermediary role, which carry the triple mission of revitalizing businesses, regions (and cluster), and secure their own well-being" (Laur 2015; pp. 23). In terms of their scope of operation, cluster initiatives can be understood as systemic intermediaries which interact at different scales: geographical with actors in other regions, administrative with authorities/ administration at regional, national and international level and in terms of industrial specialization - interaction with actors belonging to very different industries (BelsoMartinez et al. 2017). Cluster initiatives actively work to foster new partnerships and networks between the members and disseminate industry-specific information. Cluster initiatives also provide access to meeting arenas for the firms in the cluster to gather sector-specific information, developing foresight, and support joint projects (Mignon and Kanda 2018).

\subsection{Cluster initiatives and the different phases of transitions}

The life cycle approach helps to trace the evolution of the cluster in different stages: emergence, growth and maturation to decline. Furthermore, the factors which make a cluster successful during one stage may not necessarily make it successful in the other stages. In reality, very few clusters follow the life cycle model from emergence to growth to maturation to decline and there are occasional cases of clusters renewing themselves and entering new growth phases (Menzel and Fornahl 2010). The life cycle model of cluster development has been criticized for suggesting that cluster development will follow a predetermined set of activities in a linear manner from birth to growth, maturation and decline to potential renewal. Furthermore, the cluster life cycle approach does not look at the role of the external environment on the cluster development process. Relevant studies have suggested that the development paths of clusters are unpredictable, and clusters might not move from the emergence stage to the growth stage to the maturity stage in a linear manner (Martin and Sunley 2011; Trippl et al. 
2015). Despite these limitations, the cluster life cycle model serves as a heuristic device to discuss the complexity involved in the empirical case studies through a coherent conceptual framework (Frenken et al. 2015). The trajectory of cluster initiatives can take multiple development paths as their trajectory is shaped by multiple factors operating at different spatial scales. Prior studies have indicated that the cluster development follows a particular sequences of stages i.e. emergence, growth, maturity and the potential decline. Furthermore, clusters often form a part of the Regional Innovation System (RIS) and the emergence, growth, maturity and the potential decline of the clusters are better understood by understanding the specific institutional configuration, cultural aspects and knowledge infrastructure of the region (Trippl et al. 2015). Next, we discuss the activities of the different cluster initiatives in the different transition phases.

\subsubsection{Different phases of transitions}

Creating changes in the existing socio-technical systems require system innovation, and transitions are complex, non-linear and long-term processes. Systemic intermediaries must make strategic decisions about their activities, as those that are influential in one specific phase can become obsolete in the other phases (Kant and Kanda 2019; Manders et al. 2020). Existing studies have described transitions in distinct phases to simplify the complexity involved and make it possible to analyse complex large-scale structural transformations. Rotmans et al. (2001) differentiate transition processes into four distinct phases: predevelopment and exploration, takeoff, acceleration and stabilisation. In the predevelopment and exploration phase, the dominant sociotechnical regimes have not changed, but promising niche activities have emerged. In the takeoff phase, structural change is initiated. In the acceleration phase, there is a collective learning process and wider diffusion of promising niches, and in the stabilisation phase, the pace of socio-technical change decreases when dynamic equilibrium is achieved (Rotmans et al. 2001; Van Lente et al. 2003).

New studies have also merged the four different phases into the start-up, acceleration and stabilisation phases (Kanger and Schot 2016). Furthermore, studies have also indicated that the activities of systemic intermediaries shift from articulating visions of change in the earlier phases, facilitating and brokering in the successive phases and engaging in the creation of new institutional arrangements in the final phases (Van Welie et al. 2020).

The sustainability transitions literature provides useful insights connecting cluster initiatives to different transition pathways (Hermans 2018). Here, we would like to emphasize that the different transition phases are not identical to the different stages of the life cycle of a cluster; rather, cluster development is part of the transition process. The cluster development process starts later, may expire earlier and can be replaced by other activities supporting the transition. We study the activities of intermediaries in different transition phases, which have been described in recent studies (Hyysalo et al. 2018; Kivimaa and Martiskainen 2018; Kivimaa et al. 2019b). The different phases are described below.

Phase 1: Predevelopment and exploration phase In this phase, systemic intermediaries articulate the societal needs, setting new expectations and visions, lobbying for change, 
engaging in the learning process and identifying new stakeholders to mobilise change. This phase also involves small-scale temporary experimentation, such as pilot initiatives and experiments to challenge the dominant socio-technical regime, even though promising niches have not yet stabilised (Van Lente et al. 2003; Kanger and Schot 2016). Systemic intermediaries also create institutional space for facilitating promising niche solutions and finding possible configurations for socio-technical change, before the takeoff phase emerges (Kivimaa et al. 2019b).

Phase 2: Takeoff phase In the takeoff phase, niche development expands from smallscale experiments in the predevelopment and exploration phase to strategic actions that aggregate lessons from individual experiments (Van Lente et al. 2003). In this phase, systemic intermediaries create new collaborations and develop a protective space for emerging niches. However, these emerging niches face significant pressure from the dominant socio-technical regime (Kivimaa and Martiskainen 2018; Kivimaa et al. 2019b).

Phase 3: Acceleration phase In the acceleration phase, the novel niche solutions start to gradually build up and become mature, and structural change becomes visible (Kivimaa et al. 2019b). The novel niches move from experimentation in the predevelopment and takeoff phases to nurturing promising niches. In this phase, promising niches attract more users, become more mainstream and start competing directly with the dominant socio-technical regime (Van Lente et al. 2003, 2011).

Phase 4: Stabilisation phase The stabilisation phase is characterised by a slight decrease in the pace of socio-technical change, as dynamic equilibrium has resulted in an acceleration of niches that do not lead to challenging and overturning the dominant socio-technical regime (Rotmans et al. 2001; Kivimaa and Martiskainen 2018). Some intermediaries cease to exist since their role is no longer necessary, while other intermediaries create new opportunities in newly stabilised regimes (Kivimaa et al. 2019b).

We analyse the activities of the cluster initiatives in the different phases of transitions as mentioned in the prior literature (Rotmans et al. 2001; Van Lente et al. 2003; Kivimaa et al. 2019b). While few studies discuss three of the phases, namely, start-up, acceleration and stabilisation (Kanger and Schot 2016), we study all four different phases (Kivimaa et al. 2019b). Table 1 lists the activities of systemic intermediaries in the different phases.

Cluster initiatives include multiple types of activities in the different phases, and, in a few cases, these activities can overlap to some extent in the different phases. Furthermore, the cluster initiatives might be successful and influential in terms of realising their goals in specific phases and less successful and influential in other phases (Manders et al. 2020).

\subsection{Summary of the analytical approach}

Despite the promising discussions on the role of intermediaries, understanding of the activities of intermediaries in different phases of transitions is limited, as a sustained 


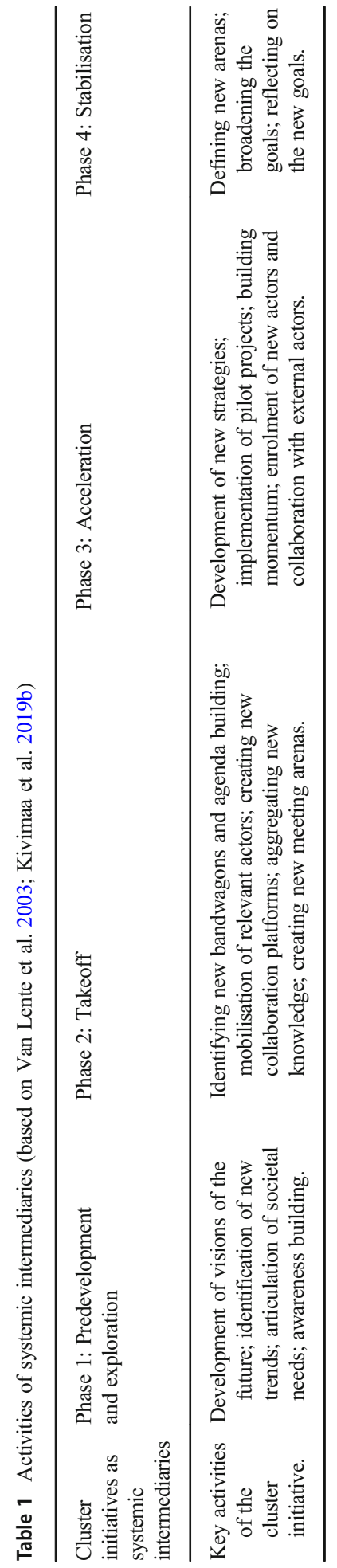


period of engagement is required to facilitate sustainability transitions (Kivimaa and Martiskainen 2018; Kivimaa et al. 2019a, b; Kant and Kanda 2019). In this paper, we utilise the concept of systemic intermediaries as introduced by Van Lente et al. (2003) and described by Kivimaa et al. (2019a), with specific attention to the role of cluster initiatives (Menzel and Fornahl 2010; Hermans 2018; Ayrapetyan and Hermans 2020). As sustainability transitions are complex, long-term processes, the concept of transition phases helps to simplify the complexity and provides a simplified view of the largescale and long-term transformation process (Kivimaa et al. 2019b). The focus on the four different transition phases is useful for exploring the diversity of activities of the cluster initiatives. We use the conceptualisation summarised in Table 1 to illustrate the different activities of the cluster initiatives in the different transition phases.

\section{Research method}

To answer the main research question, we utilised a qualitative case study approach to explore the activities of the three cluster initiatives acting as systemic intermediaries (Mignon and Kanda 2018). This approach (Eisenhardt and Graebner 2007) gives us the flexibility to explore the activities in the different phases without imposing existing analytic frameworks a priori and to include new insights that were not anticipated during the initial research design.

We chose to study the particular cluster initiatives because they have been discussed as prominent bioeconomy clusters (Sölvell 2009; Spatial Foresight 2017). The case studies were also recommended by academic, industry and regional government experts working in the field of bioeconomy development. Our case study design focused on studying the activities of the cluster initiatives by not directly comparing and contrasting the case studies but to showcase the changing activities of the cluster initiatives in the different transition phases and examine the similarities and differences between them. Instead, we aim to showcase the changing activities of the cluster initiatives in the different transition phases.

We collected archival data on the three case study regions, such as national and regional reports on bioeconomy development, regional strategy reports, newsletters, reports by the cluster initiatives, reports prepared by consultancy organisations on bioeconomy development, scientific papers, regional policy documents, company reports, websites and newspaper articles. We summarised the archival material on the three case studies independently and developed a comprehensive understanding of the cases by looking at the activities of the cluster initiatives in the different phases and their contribution to the development of a forest-based bioeconomy.

For data collection, we conducted semi-structured interviews and drew upon insights from earlier studies carried out in the three Nordic regions: Central Finland, Värmland and Trøndelag (Andersen et al. 2019). We conducted 15 semi-structured interviews in Central Finland, 15 in Värmland and eight in Trøndelag between November 2017 and November 2019. For the Swedish case study, we utilised case study material from an earlier study on bioeconomy development in Värmland (Jolly et al. 2020). In the Finnish case, due to the end of cluster initiatives before the data collection, the contemporary documents, research and evaluation reports formed the core of the study. Instead, the interviews provided important data and insights especially for the 
acceleration and stabilization phases. Interviewees in other classes included persons involved in the examined policy clusters. In total, we collected data from 38 semistructured interviews conducted in the three regions. See Table 2 for an overview of the different expert interviewees.

We prepared an interview guide based on insights from the literature summarised in Section 2. The interview guide was used as a reference to enable conservations with the experts working in the cluster initiatives rather than a strict question-and-answer approach. The interviews in the three regions were conducted independently, and the duration of the interviews was between $45 \mathrm{~min}$ and $2 \mathrm{~h}$. The interview questions helped us to understand the activities of the cluster initiatives to address barriers to bioeconomy development in the regions. The questions covered topics such as the background of the cluster initiative, its vision, networking activities, the working model and strategies for stimulating bioeconomy development. The semi-structured interviews were tape-recorded, and we also prepared notes during and after each interview. In addition to the semi-structured interviews, two industry visits were carried out in the Trøndelag region.

After carrying out the semi-structured interviews and collecting the archival data, we summarised the insights from the interview transcripts and the archival data. We first prepared individual case study summaries and examined the major institutional changes and the key disruptive events and demarcated the different activities in the cluster initiatives into distinct temporal phases (Hoffman 1999). We matched the distinct temporal phases with the four different transition phases, as described in Section 2.2. The starting and ending period of each phase for the three case studies signify key shifting points where major institutional changes occurred, resulting in a change in the focus of the activities. The temporally bracketed phases help to understand how the activities in one phase lead to changes in the subsequent phases (Langley et al. 2013). We divided the case summaries into distinct phases based on the sustainability transition process in the three regions, as described in Section 2.2. We carried out a qualitative analysis (Abdallah et al. 2019) to judge whether a particular activity fit into a particular phase and then developed a chronological story of the important activities in the different phases. The demarcation of the specific activities into specific phases was based on a comprehensive analysis of the archival data as well as insights provided by the semi-structured interviews and was not just based on the specific time periods mentioned in the regional policy documents. Therefore, the temporal phases in the three

Table 2 Semi-structured interviewees from the case study regions

\begin{tabular}{lllc}
\hline Interviewee type/region & $\begin{array}{l}\text { Central Finland, } \\
\text { Finland }\end{array}$ & $\begin{array}{l}\text { Värmland, } \\
\text { Sweden }\end{array}$ & $\begin{array}{l}\text { Trøndelag, } \\
\text { Norway }\end{array}$ \\
\hline $\begin{array}{l}\text { Local, regional or national government representatives } \\
\text { Regional cluster representatives* }\end{array}$ & 7 & 2 & 2 \\
$\begin{array}{l}\text { Firm representatives } \\
\text { Regional universities }\end{array}$ & 5 & 1 & 1 \\
$\begin{array}{l}\text { Industry networks and research institute } \\
\text { Civil society }\end{array}$ & 3 & 5 & 3 \\
\hline
\end{tabular}


case studies differ considerably depending upon the particularities of each case study (for example he predevelopment and exploration phase in Central Finland is different from in the Värmland and Trøndelag case study). Furthermore, we were aware that a few activities are similar, such as creating meeting places, in different phases due to the changed composition and size of the respective cluster initiative. The activities in the different phases might not follow a specific linear pattern, and there are several setbacks and delays in the cluster development process. We applied a qualitative coding procedure (Kant and Kanda 2019) to identify the identified activities of the cluster initiatives in the different phases (as mentioned in Table 1) and to develop an account of the cluster initiative. Furthermore, we revised our analysis of the summarised interviews and archival data multiple times to ensure the correctness and trustworthiness of the case study description provided in Section 4.

\section{Presentation of the case studies}

In this section, we present the role of cluster initiatives in the development of forestbased bioeconomy in the three Nordic regions: Central Finland, Värmland and Tröndelag. The description is divided into four transition phases as predevelopment and exploration phase, takeoff phase, acceleration phase and stabilisation phase. The time spans also represent critical phases where a new set of activities started happening which were different from the earlier activities. In the case of Arena Skog (Tröndelag), the predevelopment and exploration phase started after the predevelopment phase in Paper Province (Värmland) and the forest bioeconomy (Central Finland). In the Finnish case, we describe the clustering efforts to support the industrial transition by regional and national cluster initiatives, while in the other case studies we focus on the activities of the cluster initiatives Arena Skog and the Paper Province.

\subsection{Forest bioeconomy, Central Finland}

During the period 1994-2017, a Finnish innovation policy to accelerate the competitiveness of key sectors was implemented through two cluster programmes: the Centre of Expertise programme, as CoE (1994-2013), and the Strategic Centres for Science, Technology and Innovation, as SHOKs (2006-2015/2017). The CoE was a special temporary government programme that was originally a part of the general economic restructuring of the Finnish economy in the 1990s. The core idea was to generate business based on regional strengths and to make connections between industries, research and public administration. In general, the technology/science parks managed the regional CoEs. Projects were the way to execute this programme, for which the CoEs provided seed funding. However, the majority of the financing came from other public sources. The $\mathrm{CoE}$ in Central Finland was called the Jyväskylä Centre of Expertise programme (Ahola and Kortelainen 1996, pp. 19-20; Osaamiskeskusohjelma, Tuloksia ja käytäntöjä 2007-2013, p. 5; Vilhula et al. 2006; Heikkinen 2007.) The SHOK programme was established following the guidelines of the Finnish Science and Technology committee. The SHOKs were organised and managed only as nationwide cluster organisations of companies and research organisations, with special intermediary organisations to manage the cluster operations. The 
SHOKs did not have their own R\&D financing, but they channelled private (company) and earmarked public funds through research programmes they defined themselves (Lähteenmäki-Smith et al. 2013; Wallin and Laxell 2013). In Central Finland, these two cluster initiatives, the Jyvskylä $\mathrm{CoE}$ and the Forest cluster of the SHOK, have fostered the transition from the traditional forest industry to the forest bioeconomy.

\subsubsection{Predevelopment and exploration (1999-2006)}

Despite the worldwide view on the forest industry as a sunset field, Central Finland expressed trust in its forest sector's capability to maintain and further develop its highlevel competitiveness (Keski-Suomen maakuntasuunnitelma 2006, p. 17; Interview data). With focal points parallel to the regional plan, the cluster initiative Jyväskylä $\mathrm{CoE}$ focused on technologies related to paper production, energy and the environment, eventually adding nanotechnology in 2003. The aim was to build new networks between regional industries, universities and the regional government. At that time, along with general technology park services and facilities, Jyväskylä Science Park (JSP) managed the Jyväskylä CoE, providing the overall framework for a variety of CoE projects and helping them to obtain funding (Ahola and Kortelainen 1996, pp. 5055; Koskenlinna et al. 2005, pp. 1, 56, 65-68; Suvinen et al. 2010; Vilhula et al. 2006, pp. 56-58).

In 2006, the nationwide SHOK programme began with the (a) forest, (b) energy and (c) machinery and equipment industries as three of the six initial industries starting as cluster organisations (Lähteenmäki-Smith et al. 2013). In 2006, the forest cluster set a target to double, through research, the value of the products and services of the forest industry by 2030 . Significantly, the Central Finland region had direct connections to the forest cluster, as forest companies including Metsä Group (then Metsäliittokonserni) and UPM-Kymmene, in addition to the University of Jyväskylä and VTT Technical Research Centre of Finland Ltd., were members of this cluster and were stakeholders of the innovation company, Forestcluster Ltd., which managed the cluster operations (Suomen metsäklusteriin ... News 2007).

\subsubsection{Takeoff (2007-2010)}

Later in the decade, the transition from traditional industry to a forest-based bioeconomy experienced a clear takeoff. On a regional level, Jyväskylä CoE (programme period 2007-2013) motivated this with the following focal points: (1) future energy systems emphasizing bioenergy and energy usage of the forest industry, (2) renewing the forest industry as paper production technologies and (3) nano- and microsystems as well as future materials, including packages, composites, filters, catalysts and sensors. While JSP was replaced by Jyväskylä Innovation Ltd. in terms of the Jyväskylä CoE management, JSP and other science centres were in charge of each of Jyväskylä CoE's focal themes. Overall, the cluster initiative Jyväskylä $\mathrm{CoE}$ was able to connect, along with other firms, the local representatives from big national forest companies, such as UPM-Kymmene and Metsä Botnia, and consultation companies, such as Pöyry. In addition, the Jyväskylä University of Applied Sciences, University of Jyväskylä and VTT executed this programme. The overall project volume of Jyväskylä CoE was 163 
projects, with a total expenditure of 32.5 million euros (Heikkinen 2007; Osaamiskeskusohjelma ... 2007-2013, p. 65).

While the CoE programme, in general, was organised, managed and executed by the regions, during 2007-2013 the regional CoEs also formed thematic nationwide networks (Osaamiskeskusohjelma ... 2007-2013: 5). The Jyväskylä CoE was a member of (1) the Renewing Forest Industry and (2) the Future Energy Technologies clusters (Heikkinen 2007; Wallin and Laxell 2013, p. 54, 85). Furthermore, the former supported SMEs by highlighting their role in the forest sector, supporting them to join relevant national programmes and scanning and informing new business possibilities when a transition from the traditional forest industry to the bioeconomy became evident (Osaamiskeskusohjelma ... 2007-2013, p. 62). While the Jyväskylä CoE was a member of the two nationwide cluster networks, these two clusters collaborated with SHOK clusters, such as CLEEN (Energy and Environment cluster) and FIBIC (Finnish Bioeconomy cluster) (Wallin and Laxell 2013, p. 54, 85).

The forest cluster clarified and updated its future goals, emphasizing forest industryrelated cleantech and bioeconomy. Projects were to be focused on basic research, upon which R\&D would be based (Interview data; Lähteenmäki-Smith et al. 2013; Finnish Forest Industries 2010). All in all, the SHOK programme operated at its fullest level between 2008 and 2015, with a total financial volume as $1114 \mathrm{Mrd} €$ (Kaupallistamista ja kansainvälisyyttä... 2016, p. 8).

\subsubsection{Acceleration (2010-2014)}

The year 2010 was a clear turning point. In that year, the national forest cluster released a new research strategy. The main goal form 2006 was still relevant, but the focal points of research were (1) the customer and user as the drivers of development, (2) possibilities offered by new materials, services and business models and (3) the forest cluster as a builder of a sustainable bioeconomy. The forest cluster not only comprised the forest industry but also a wide range of industries, including forestry, logistics companies, machine and equipment manufacturers, energy producers, the construction sector and consultants (Forest cluster 2010). Development programmes like FuBio, future biorefinery (2010-2015), were executed. Evaluation of the forest cluster's activities revealed that the cluster was an essential part of the renewal and change of the Finnish forest sector (Lähteenmäki-Smith et al. 2013, p. 105; Interview data).

Both major forest companies operating in Central Finland started to gradually implement a green paradigm in their strategies and operations. This also affected their business networks, as they, for example began to demand certified wood (Interview data; Metsä Group 2012; UPM 2019). A significant moment occurred in 2014, when Metsä Group announced it was replacing its old pulp mill with a new bioproduct mill (1.2 Mrd $€$ investment) in its industrial site in the northern part of Central Finland (Metsä Fibre 2014) Beyond the large scope of products (pulp, biochemicals, bioproduct and sulphuric gases, lignin and textile fibres, bioelectricity), the total use of the wooden material, side-streams and effluents - in addition to the non-use of fossil fuels and the delivery of bioelectricity and heat to external users-positioned the group as the flagship of the forest-based bioeconomy locally, regionally and nationally. In addition, the idea of an industrial ecosystem to exploit the material flows of industrial production 
provided a way to connect new businesses with existing ones to promote bio- and circular economies (Metsä Fibre 2017, Interview data).

\subsubsection{Stabilisation (2015-2019)}

In 2015, when the new prime minister and his government took office, the innovation policy landscape changed dramatically in Finland (Sotarauta and Suvinen 2019). The entire CoE programme had already ended in 2013, and no replacement was launched. Jyväskylä Innovation also ceased in 2015. The SHOKs ended in 2015-2017 (Sotarauta and Suvinen 2019). Forestcluster Ltd. had already merged with the FIBIC (Finnish Bioeconomy Cluster Ltd.) in 2012. When FIBIC subsequently merged with CLEEN (Energy \& Environment), in 2015, this constellation became CLIC Innovation Ltd. This organisation defines its existence as follows: 'CLIC Innovation is an open innovation cluster with the mission of creating breakthrough solutions in bioeconomy, circular economy, and energy systems' (CLIC Innovation 2018). After the SHOK programme, the remaining intermediary organisations continued in one form or another, but no earmarked public funds were directed to their operations or projects.

In Central Finland, this new situation meant no large-scale policy-driven development or clustering efforts were executed related to forest-based bioeconomy. However, some R\&D projects were supported by public financing from regional authorities (Hankeraportti 2018; Interview data). Overall, the industrial networks and collaboration projects between research institutions and companies of all sizes were the nexuses for forest bioeconomy development (interview data).

In this phase, the big companies had a clear leading position to define new arenas and goals while scaling up the forest-based bioeconomy in the region. Here, the Metsä Group's new mill (opened in 2017) with its industrial ecosystem was an excellent example. The new sustainable industry and ecosystem thinking had a naturally wide influence on the mill's business networks. In addition, the town, with the aid of a consultation company, Vision Hunters, published a special bio- and circular economy brand, discovered business potential for new companies to operate and searched for potential firms to locate to its area (interview data; Vision Hunters 2018). On a regional level, the policymakers highlighted that a new direction for the region's forest industry with new products and production had been opened by the new bioproduct mill (KeskiSuomen maakuntaohjelma 2018-2021).

\subsection{Paper Province, Värmland}

\subsubsection{Predevelopment and exploration (1999-2004)}

In the predevelopment and exploration phase, Paper Province created a unique local knowledge and competence centre for the pulp and paper industry (Sölvell 2009; Sörensson and Jonsson 2014). The industry was undergoing structural changes and facing crises due to the need for economies of scale and strong environmental regulations (Van Vught et al. 2006; Mikkola et al. 2016). The regional Karlstad municipality, the county council and the County Administrative Board of Värmland initiated the cluster initiative Paper Province in 1999 to address these ongoing crises. Initially, seven firms operating in the pulp, paper and machinery sector took part in Paper Province to 
cooperate with each other and improve their competitiveness (interview, consultant for cluster development; interview, Sölvell 2009).

Key representatives from Paper Province engaged in advocacy efforts and visited the different firms in the Värmland region and tried to convince them to become members. The representatives also identified motivated people within the firms who were interested in changing the dominant ways of working in the regional industry and who were willing to become a part of the new cluster initiative Paper Province and expand the network (interview, consultant for cluster development). The experts worked together to understand how the different regional stakeholders could cooperate with each other instead of competing against each other to develop a regional strategy for promoting a forest-based bioeconomy in the region (interview, consultant for cluster development).

\subsubsection{Takeoff (2004-2013)}

During the second phase, the cooperation between the different firms in Paper Province was strengthened, and the different regional stakeholders developed new relationships with each other based on a common vision for a forest-based bioeconomy in the region (interview, CEO, regional cluster). Paper Province received support from the regional authority Region Värmland and launched an independent industrial research firm, the Packaging Greenhouse, of offer services such as paper testing, pilot machine trials and education. The Packaging Arena, launched in 2004, and the Packaging Greenhouse became an important avenue and meeting place for cooperation between the Paper Province, Region Värmland, Karlstad University and the firms in the region (Chen 2009).

Paper Province further provided opportunities to develop meeting places between different regional stakeholders in Värmland and to enhance regional cooperation to support the regional development strategy in the Värmland region (Sölvell 2009). In 2007, Paper Province was one of the 16 top European clusters in high innovation regions. In 2010, the cluster was named one of the top 100 European World Class Clusters by the European Cluster Observatory (Hallencreutz 2018). In 2012, Region Värmland also developed and published its new regional development cluster strategy 'Värmland model 2.0', establishing new priorities for regional development and for integrating with the EU's regional support programmes (European Structural fund ERDF and European Structural Funds ESF) (Lindqvist 2012). The cluster strategy was part of the regional development strategy, Värmlandstrategien 2014-2020, and aimed at accelerating the development of existing clusters and increasing their global visibility (Goddard et al. 2013).

\subsubsection{Acceleration (2013-2017)}

During the acceleration phase, Paper Province 2.0 was formed in 2013, which received SEK 130 million funding from Vinnova as part of the Vinnväxt programme. The programme sought to position the Värmland region as a key demonstrator of bioeconomy and involved a partnership between Karlstad University, Region Värmland, the County Administrative Board of Värmland and the forest stakeholders in Värmland (interview, strategist, regional growth development, regional development agency; Grundel and Dahlström 2016; Hallencreutz 2018). 
The other types of initiatives with which Paper Province interacted included the Karlstad Innovation Park, the Sting Bioeconomy and the Kickstart network and Lignocity (Region Värmland 2019). The Karlstad Innovation Park supported entrepreneurs and organised several events to develop new products and services (Aalto 2019). The Sting Bioeconomy and the Kickstart network Värmland are one of the leading incubators for supporting start-ups involved in the forest-based bioeconomy in Värmland. Another initiative, Lignocity, which is a testbed for supporting forestbased bioeconomy, has been instrumental in developing applications related to lignin (Interview, Project Manager, Bioeconomy Incubation Network; Interview, Director, business development, research institute).

The Värmland region instituted the Smart Specialisation Strategy (2015-2020), which prioritised the forest-based bioeconomy. The strategy was initiated together with Karlstad University, Region Värmland and other regional stakeholders (Henriksson 2016; Grundel and Dahlström 2016). In 2016, a new initiative called the Academy of Smart Specialisation was formed between the Värmland region and Karlstad University to renew the forest industry in Värmland through stakeholder interaction (Academy for Smart Specialisation 2016).

\subsubsection{Stabilisation (2017-2019)}

During the stabilisation phase, Paper Province played an instrumental role in fostering cooperation between different members, including large firms, start-ups, regional authorities, civil society, industry associations and forest owners. Furthermore, Paper Province interacted with Vinnova and provided a platform for all the regional stakeholders to meet with each other, share their experiences and develop joint strategies for promoting a forest-based bioeconomy in the region (OECD 2006; Mikkola et al. 2016). In 2017, Paper Province also achieved Gold Status, which is the highest possible distinction for cluster management within the EU (Paper Province 2017). The Paper Province is working toward the UN 2030 agenda to facilitate inclusive economic growth and improve the competitiveness of the industry, to create avenues for a circular economy by replacing fossil raw materials with forest-based biomaterials and to advocate for gender equality in the forest industry in Värmland.

Paper Province participated in the Bioinno initiative, a collaboration between the Värmland and Dalarna regions for working together on forest-based innovations. Furthermore, Paper Province established collaboration with networks outside of Europe and planned to work together on the development of new products and services from Lignin with CRIBE (Center for Research and Innovation in the Bioeconomy) based in Ontario, Canada (Paper Province 2019).

Region Värmland developed a collaboration with initiatives outside the Värmland region, namely, the ERRIN (European Regions Research and Innovation Network) network, Vanguard initiative and the Interreg project (the Bioeconomy region). The Nordic Council of Ministers launched different initiatives related to Bioeconomy (e.g. Nordic Bioeconomy Panel, BioLab) in which the Värmland region participated (Henriksson 2016). The Bioeconomy region is an interregional project between Norway and Sweden that was initiated in 2017 and seeks to help small and medium-size firms to develop new products, technologies and services in the field of bioeconomy and to achieve a larger market share (Paper Province 2017; Aalto 2019). 


\subsection{Arena Skog, Trøndelag}

\subsubsection{Predevelopment and exploration (2004-2015)}

In the first phase, the Norwegian forest-based industry, in general, was in crisis. Several large pulp and paper plants closed down, and the framework conditions for the industry in Norway were much worse compared to their neighbours in Sweden. The largest companies in the pulp and paper industry were highly specialised and locked into the production of print paper, which experienced a decreased international demand. The forestry companies struggled with the lower quality of the roads compared to Sweden and different taxation and fee regimes. As a result, there was a short-term focus on the export of cheap timber to Sweden and the use of forest resources for stationary energy.

This critical situation was also typical for the two Trøndelag counties, Southern Trøndelag and Northern Trøndelag, which have since merged into one county. Here, the forest-based industry combines several value chains and collaborates with strong competence centres in Trøndelag and outside the region. Forest properties were highly fragmented in Trøndelag as in Norway in general. However, there were different challenges in inland Trøndelag and the coastal forestry sector of Trøndelag. In the coastal area, the forest-based industries lacked raw forestry materials.

In 2005, the 'Coastal Forestry Project' (Kystskogbruket) was founded on the initiative of the County council in Nord-Trøndelag to address this crisis. The cooperation was based on three main pillars: a joint political programme at the county level, a collaboration between the coastal forest-based industries and a group of forestry specialists in the counties' administration. In 2004/2005 the collaboration forum 'forest industries in Trøndelag' (Skognæringa I Trøndelag) was established as a result of a political initiative of the county councils of the two Trøndelag counties. This forum also became a member of the Coastal Forestry Project. In the years after its foundation, the main emphasis was on improved framework conditions for the forest-based industries in Trøndelag. With the crisis described above, the 'Forest industries in Trøndelag' realised that society, in general, needed a better understanding of this industry and that meeting places and arenas were needed to discuss both the industry's framework conditions and more professional issues.

In response to this crisis, in June 2013 the Ministry of Trade and Industry issued a White paper on industry development (Nærings- og handelsdepartement 2013). This White paper presented some strategic priorities for certain industries, including the forest-based industries. Some of the highlighted political instruments for improving the framework conditions of this industry were measures for improved transport of forest resources in the National Transport Plan 2014-2023, an additional 500 million NOK investment for the forest industry administered by Investinor, 75 million NOK to provide financial support for innovation and R\&D administered by Innovation Norway (the Norwegian Government's instrument for enhancing innovation) and the Research Council of Norway (RCN), 75 million NOK for infrastructure measures administered by the Ministry of Agriculture and Food and 100 million NOK for improved transport possibilities administered by the Ministry of Transport. The White paper also mentioned plans for a strategy group for the forest industry (Skog22) (Nærings- og handelsdepartement 2013, p. 183). The government-appointed this strategy group for the forest industry (Skog22), with broad participation from both industry and 
government. In the beginning of 2015, the final Skog22 report on forest-based industry development was published. The Skog22 report consisted of four sub-reports on forestry, energy, fibre and biorefinery and wood-based construction (Venn 2015).

In 2014, forest industries in Trøndelag developed a proposal for getting the status of an arena cluster under the umbrella of Innovation Norway, SIVA (the governmental organisation for the development of a national infrastructure for innovation and industrial growth) and RCN. The first proposal for a cluster initiative was submitted in 2015 but was not successful. However, the collaboration forum developed the proposal further to include prioritised projects and to be more specific concerning the collaboration for developing a bioeconomy, including $R \& D$ organisations and actors active in aquaculture and construction as new possible development pathways for the future cluster. In the beginning of 2015, there was an important debate about the role of collaboration between forest owners for the development of forest-based industries. In 2016, the Arena Skog received the cluster status.

\subsubsection{Takeoff (2016-2017)}

In the second phase, the established cluster initiative Arena Skog included not only traditional forestry actors but also industrial companies specialised in processing wooden resources, such as pulp and paper plants, and companies that could process residues from these companies as well as from aquaculture (e.g. a company specialised in producing biogas). There were 15 core members ( 4 forest owner companies, 7 wood processing companies, 3 forestry entrepreneurs and 1 non-profit organisation), 10 cluster companies and several wooden construction firms and other types of firms processing forest resources. The cluster initiative also included two incubators, innovation and information companies and $12 \mathrm{R} \& \mathrm{D}$ organisations. Some of these members were located outside the region and did not exclusively work on regional issues. Most of the members were located in the region, although some were located elsewhere and had a national agenda. In this phase, Arena Skog developed projects in the following areas: (1) the use of wooden fibre in new products and value chains (a) as a feedstock for fish and animals, (b) for composite materials and (c) for packaging, hygiene and tissues; (2) increased use of wood through standardised products and (3) increased felling activities and improved logistics systems to ensure a better supply based on regional forest resources.

Arena Skog mediated between different industry sectors, creating meeting places for developing new ideas for business development across traditional industries and value chains. The cluster organisation included the largest forest industry incumbents, such as the large forestry companies Allskog, Norskog, SB Skog and Statskog, forest-based industry companies Norske Skog Skogn, MM Karton Follacell, Kjeldstad Trelast, InnTre, Støren Treindustri and a subsidiary of the Moelven industry group as well as important entrepreneurs from these forestry companies.

The industry interacted with the non-profit organisation Skogselskapet Trøndelag, focussing on increased value creation and on long-term, sustainable management of the forest in Trøndelag, with the national information company Trefokus, specialised in providing information about wooden construction, and with Kvinner I Skogbruket, an ideal national organisation supporting women's engagement in forestry. 
Moreover, the cluster initiative interacted with Innovation Norway through its Forest Bioeconomy programme and its cluster programme and SIVA, a public enterprise supporting incubation and business gardens in Norway. The national agency Innovation Norway has regional agents (e.g. Tredrivere) in different regions. The regional agents include experts who support smaller firms and start-ups in the forest-based industry with issues regarding markets, collaborations, policies, machinery imports and even employee education and recruitment. There were also incubators, Fiborgtangen Vekst AS and Proneo AS, as well as several R\&D partners, which contributed not only with R\&D but also with providing courses and further education, such as Skogbrukets Kursinstitutt and Norsk Treteknisk Institutt.

There were promising R\&D directions involving new uses of wood fibres: woodfibre-based fish and animal feed as well as other wood-fibre composites. The main challenge was developing these new types of fibre-based products at a cost that would be profitable in a realistic market. At the same time, entering the expanding market of wood construction products, especially through the standardisation of products for wood construction, became a priority. A general need for exploring all these directions was to ensure a stable supply of raw materials both in the short and long term. Arena Skog was not just organising projects but also courses for further education and meeting places to address relevant issues for the involved industry actors.

\subsubsection{Acceleration (2017-2019)}

In the third phase, Arena Skog collaborated with other industry clusters regionally, nationally and across borders, such as Future Biorefinery (Sweden), NCE Aquatech, Norwegian Wood (started 2017), Paper Province (Sweden) and Foods of Norway (NMBU). Collaboration with innovation intermediaries such as Innveno AS intensified. The collaboration of Arena Skog with the 'Coastal Forestry Project' also had some political advantages: the regional authorities and politicians were conscious of the challenges related to forest-based industry development in Trøndelag and had formulated political strategies and plans to address those challenges (Fylkesmannen I Trøndelag 2019; Trøndelag County Authority 2017).

Arena Skog also participated in national and international research and development projects, such as the Horizon 2020 project 'Build in Wood', which was initiated by the Nordic Network for Tall Wood Buildings, and which was again started by Arena Skog in collaboration with Innobygg and Smart Housing Småland in 2017 (Skatvedt 2019). Arena Skog collaborated with other industry clusters, both nationally and internationally, to spur regional path creation for the bioeconomy: Foods of Norway (NMBU), NCE Aquaculture, Norwegian Wood (started 2017), Future Biorefinery (Sweden), Paper Province (Sweden) and most recently with the Norwegian Tunnel Safety Cluster and the Solar Cluster.

In 2019, the cluster initiative thus sought to take the step up to the next cluster level - as an Arena PRO cluster-with increased ambitions and an emphasis on continued growth and commercialisation. In 2019, Arena Skog entered into a formal collaboration with several other clusters, such as the Norwegian Tunnel Safety Cluster and the Solar Cluster. The goals for the new cluster proposal were supported by the forestry sector and forest-based industries as well as by the political parties in the Trøndelag region. 


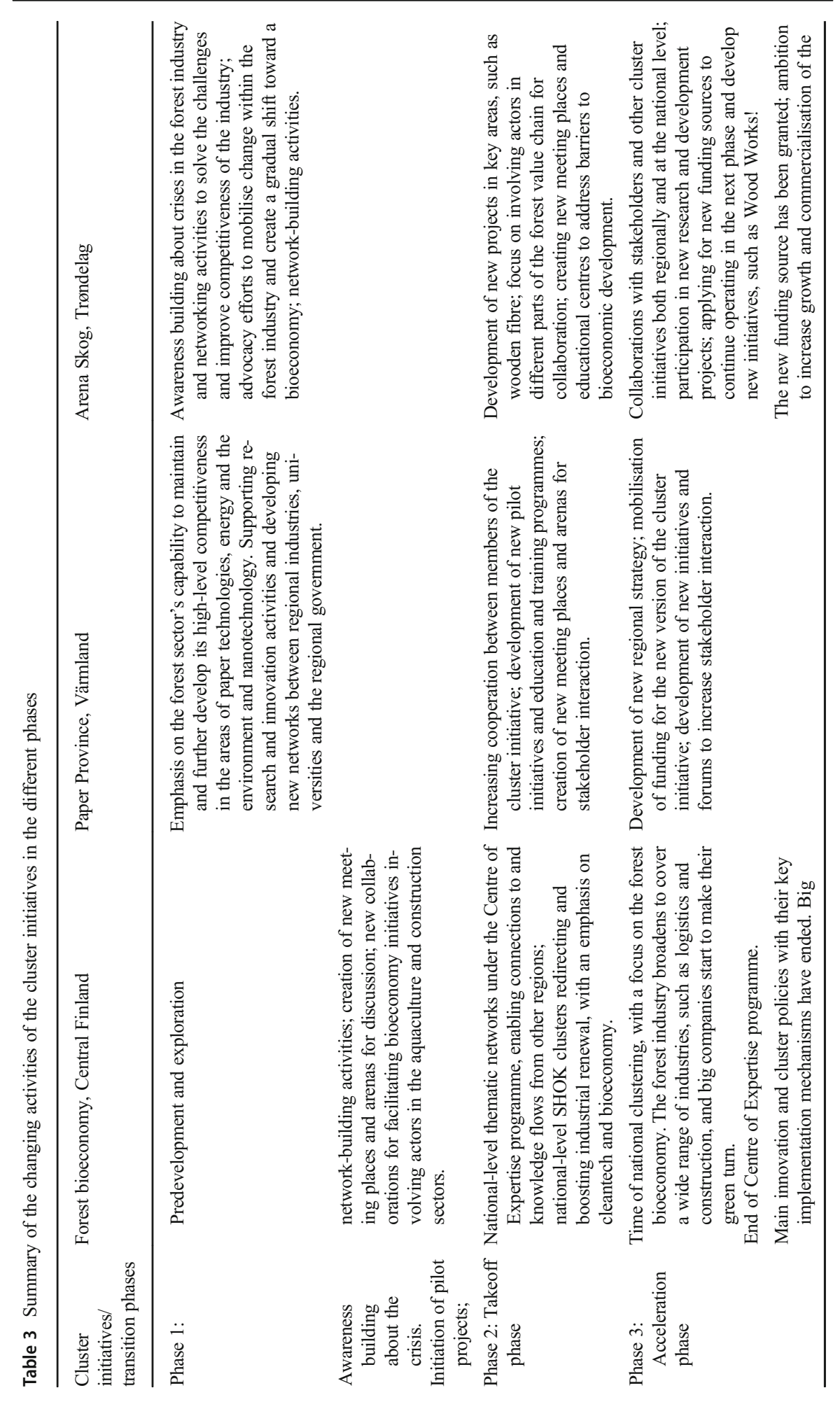




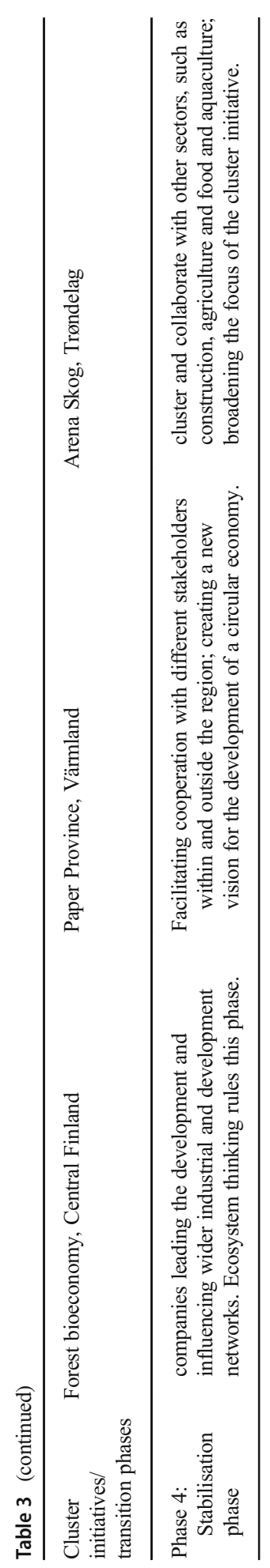

\section{Springer}




\subsubsection{Stabilisation (2019-onwards)}

In the fourth phase, the cluster initiative succeeded in becoming an Arena PRO cluster, a higher-level innovation cluster, with funding secured for the next 5 years and a changed name: Wood Works! cluster. The cluster will extend its collaboration with other sectors, such as aquaculture and agriculture-based industries in Trøndelag, to exploit possibilities for value creation based on the interaction of different sectors in the region. The new Wood Works! cluster initiative will broaden its activities in central Norway, not just in Trøndelag, but the whole of Norway is its field of impact in addition to international activities and relations. The industries now include more sectors besides forestry, wood processing, construction, aquaculture and agriculture - all seeking to find new and innovative products involving wooden resources, whether as a material resource, as a feedstock, etc.

\section{Discussion}

Our study provides a rich empirical illustration of the activities of cluster initiatives in the different transition phases. We show that, rather than fulfilling one specific type of activity, cluster initiatives engage in multiple activities in response to the changing contextual conditions. In Table 3, we highlight the different activities of the cluster initiatives acting as systemic intermediaries in the transition toward a bioeconomy. The table summarises the changing activities in the different phases.

\subsection{Predevelopment and exploration phase}

This phase differs in the three cases with regard to the timing, main aim and specialisation:

Timing: Forest bioeconomy and Paper Province began their gradual change toward a forest-based bioeconomy in 1999, while Arena Skog first followed this line in 2004.

Main aim: The crisis of the forest-based industries in the 1990s in Värmland was the starting point for forest-based cluster development in this region, while in Central Finland the development was part of the general economic restructuring of the Finnish economy in the 1990s. The CoE programme was introduced to find a way out of this economic depression, and hence the awareness building of the future direction had started years before the bioeconomy discussion. As the Finnish case shows, the predevelopment phase is about networking between industry, research and government and learning how to act as a cluster, and the direction of the forest-based bioeconomy can be found in the three $\mathrm{CoE}$ themes. For Sweden and Norway, this phase was mainly about awareness building about the crisis in the forest industry and the need for better framework conditions for the industry. In both clusters, networking activities to solve the challenges of this industry became crucial. 
Specialisation: Natural endowments and existing industrial specialisations have influenced the options for new path development in all three regions. For example, we can see a very strong specialisation in the forest-based industries and bioeconomy in the Swedish and Finnish cases, whereas the Norwegian case did not have such a strong specialisation, and other bioeconomy sectors (e.g. aquaculture) were strong in Trøndelag as well.

\subsection{Takeoff phase}

In the takeoff phase, in Central Finland the cluster initiative Jyväskylä CoE increased its networking activities and collaboration with actors operating at the regional and national level while in the case of the Paper Province and Arena Skog the emphasis was on creating new meeting arenas and meeting places for increasing stakeholder interaction in the region. This phase shows some clear differences between the three cases regarding the national ambitions of the regional clusters. In this phase, Central Finland took real steps toward a forest-based bioeconomy by clarifying its regional focal points and, especially, by adapting itself to national-level clusters. While the key activities identified in the Värmland and Trøndelag cases were also similar in Central Finland, the linkage formation enabled new connections and knowledge transmission from other regions. Furthermore, the core position of the forest cluster at the national level moved Central Finland to the head of forest sector's green turn. Overall, the two cluster programmes enabled the takeoff toward the industrial transition. In the case of Arena Skog, more attention was given to becoming a regional cluster for the forest-based bioeconomy, with less focus on the national level, while the case of Paper Province shows intense regional interaction but also interaction with other European and global actors.

\subsection{Acceleration phase}

In this phase, the cluster initiative Jyväskylä CoE in Central Finland developed new roadmaps and programmes for bioeconomy development and funding mechanisms, Paper Province prioritised funding activities for the development of the new version of the cluster initiative and Arena Skog focused on enhancing collaboration with other cluster initiatives in other regions and at the national level. This phase was different in Finland and in the two Scandinavian countries: while Central Finland could now start to harvest the good results of the earlier processes, the other two clusters developed further as clusters but with strong interactions with actors outside of their regions. Arena Skog reached out of its region and interacted with several other clusters specialised in different industries. In Central Finland, this is the phase in which the national-level connections and activities of both cluster organisations, CoEs and the forest cluster, accelerated the transition to the forest-based bioeconomy. Many of the national forest cluster's focal points - and especially the future biorefinery programme - actualised themselves in Central Finland. In addition, as an outcome of cluster participation and activities, big companies began their green turn, both in their national-level strategies and regional-level operations. 


\subsection{Stabilisation phase}

In the stabilisation phase, Paper Province and Arena Skog started new initiatives in the area of the circular economy. The new Wood Works! cluster in Trøndelag secured additional funding for realising these ambitious plans. Along with the other outcomes, the Central Finland case is an example of how the evolution of the industrial transition finally made the intermediary organisations useless, as their work had been done. The industry took the lead and was capable to develop much on its own or in collaboration with research.

For the development of Central Finland's forest-based bioeconomy, the national level forest cluster has played a more profound role. We have also seen that, in the case of Central Finland, the discontinuity of developed collaboration structures opened up new interaction patterns of more project-oriented collaboration, platforms and industrial ecosystems, while in the Värmland and Trøndelag cases, the focus was more on broadening the scope of the cluster activities while maintaining its traditional focus.

\section{Conclusion}

This article develops and operationalises an analytical approach for analysing the changing activities of intermediaries in the different phases of transition. Our research question was as follows: Which activities do cluster initiatives engage in the different phases of transition to facilitate the development of a forest-based bioeconomy in the Nordic regions? We discuss the activities of the cluster initiatives in the four different phases of transitions: (1) predevelopment and exploration, (2) acceleration, (3) takeoff and (4) stabilisation. Our study shows that the cluster initiatives follow a different set of activities (see Table 3) in different phases.

Our paper connects the literature on systemic intermediaries (Van Lente et al. 2003, 2020; Kivimaa et al. 2019b) with that on cluster initiatives (Laur 2012; Laur 2015) and contributes to the ongoing debates on the micro-dynamics of bioclusters and the link between cluster development and transition pathways through a longitudinal analysis (Hermans 2018; Ayrapetyan and Hermans 2020). Furthermore, the paper contributes to recent debates on adopting a spatial perspective (Van Boxstael et al. 2020) to study the activities of cluster initiatives based in Central Finland, Värmland and Trøndelag. As prior literature has suggested that more research is required on the role of systemic intermediaries and their activities at different spatial scales in the different phases of transitions (Hodson et al. 2013; Kant and Kanda 2019; Kanda et al. 2020), we also contribute to a better understanding of the changes in the activities of cluster initiatives in different institutional contexts.

Future research could investigate the ecology of intermediaries (Barrie and Kanda 2020), as we explored the activities of one specific type of systemic intermediary (cluster initiatives). Systemic intermediaries often may not have a significant impact individually in terms of contributing to sustainability transitions, and often the cumulative impact of multiple types of intermediaries is necessary for generating a significant impact (Manders et al. 2020). There is a need to explore the role of the ecology of intermediaries and to better understand the complementarities and conflicts between them for facilitating sustainability transitions (Kivimaa and Martiskainen 2018; 
Kivimaa et al. 2019b). New research is required to explore why different cluster initiatives can sometimes come in conflict to each other. A limitation of the research is that we study the activities of the three cluster initiatives and compare and contrast them but could not explain the drivers for the differences in the activities. There is a need to explore the relationship between the development of cluster initiatives and the institutional environment and how the actions of the national state affect the development of cluster initiatives (Fornahl et al. 2015). Novel insights are also required to understand if specific institutional differences between the different countries influence the activities of the cluster initiatives by conducting more cross case analysis across different countries (Konstantynova and Lehmann 2017). Future research can build on the results and develop a typology of different activities of the cluster initiatives and develop more generalisable insights about the different stages of the cluster initiatives.

Based on our results, future studies can explore the effectiveness of the cluster initiatives in terms of their organisational design, governance model, objectives, the scope of activities and source of funding (Kant and Kanda 2019; Kanda et al. 2020) and the extent to which they can support their activities despite funding constraints. New studies could also look into how policymakers can continuously monitor the activities of intermediaries over time, identify the missing roles and establish new intermediaries to fill the gaps or create synergies between the activities of the ecology of intermediaries.

Funding This research work was carried out within the GONST (Geography of Nordic Sustainability Transitions) project, funded by the Nordic Green Growth Research and Innovation Programme in cooperation with NordForsk, Nordic Innovation and Nordic Energy Research [Grant no. 83130].

Open Access This article is licensed under a Creative Commons Attribution 4.0 International License, which permits use, sharing, adaptation, distribution and reproduction in any medium or format, as long as you give appropriate credit to the original author(s) and the source, provide a link to the Creative Commons licence, and indicate if changes were made. The images or other third party material in this article are included in the article's Creative Commons licence, unless indicated otherwise in a credit line to the material. If material is not included in the article's Creative Commons licence and your intended use is not permitted by statutory regulation or exceeds the permitted use, you will need to obtain permission directly from the copyright holder. To view a copy of this licence, visit http://creativecommons.org/licenses/by/4.0/.

\section{References}

Aalto A (2019) Building bioeconomy innovation ecosystem in cross-border and rural context. JAMK University of Applied Sciences, Jyväskylä. Retrieved from https://www.jamk.fi/globalassets/tutkimusja-kehitys\%2D\%2Dresearch-and-development/tki-projektien-lohkot-ja-tiedostot/rdi2club/materials/ report_rdi2club_benchmarking_hedmark_varmland2018.pdf. Accessed 10 Jan 2020

Abdallah C, Lusiani M, Langley A (2019) Performing process research. In: Boyd B, Russel CT, Lê JK, Smith $\mathrm{AD}$ (eds) Standing on the shoulders of giants: traditions and innovations in research methodology. Emerald, Bingley, pp 91-114

Academy for Smart Specialization (2016) Academy for Smart Specialisation, 2016-2020. Region Värmland. Retrieved from https:/www.kau.se/files/2017-09/Appendix\%20Academy\%20for\%20smart\% 20specialisation.pdf. Accessed 12 Nov 2019

Ahola E, Kortelainen S (1996) An evaluation of the Centre of Expertise Programme (in Finnish). Helsinki, Ministry of the Interior, Department for Development of Regions and Public Administration, Publication 17, Helsinki 
Andersen AD, Bugge M, Capasso M, Jolly S, Klitkou A, Sotarauta M, Steen M, Suvinen N (2019) Green growth in Nordic regions: eight case studies. In: NIFU Working Paper, 122. Nordic Institute for Studies in Innovation, Research and Education, Oslo

Ayrapetyan D, Hermans F (2020) Introducing a multiscalar framework for biocluster research: a metaanalysis. Sustainability 12:3890

Barrie J, Kanda W (2020) Building ecologies of circular intermediaries. In: Brandão M, Lazarevic D, Finnveden G. Handbook of the circular economy. Edward Elgar, Cheltenham (forthcoming)

Bauer F, Hansen T, Hellsmark H (2018) Innovation in the bioeconomy - dynamics of biorefinery innovation networks. Tech Anal Strat Manag 30:935-947

Belso-Martinez JA, Expósito-Langa M, Mas-Verdú F, Molina-Morales FX (2017) Dynamics of brokerage positions in clusters: evidence from the Spanish foodstuffs industry. Sustainability 9:18

Capasso M, Klitkou A (2020) Socioeconomic indicators to monitor Norway's bioeconomy in transition. Sustainability 12(8):3173

Chen J (2009) Value creation through services in manufacturing cluster. Master thesis. Faculty of Economic Sciences, Communication and IT. Department of Business Administration Karlstad University. Retrieved from http:/www.diva-portal.se/smash/get/diva2:235091/FULLTEXT01.pdf. Accessed 15 Apr 2019

Clic Innovation (2018) https://clicinnovation.fi/. Accessed 24 Apr 2018

Cooke P (2007) Growth cultures: the global bioeconomy and its bioregion. Routledge, London

Eisenhardt KM, Graebner ME (2007) Theory building from cases: opportunities and challenges. Acad Manag J 50:25-32

Finnish Forest Industries (2010) Forestcluster Ltd's research portfolio leans towards new products and technologies, biorefineries and customer solutions. https://www.forestindustries.fi/news/forestclusterltds-research-portfolio-leans-towards-new-products-and-technologies-biorefineries-and-customersolutions. Accessed 19 Nov 2019

Forest cluster research strategy (2010) The world's leading forest cluster 2030. https://www.metsateollisuus.fi/ uploads/2017/03/30041804/890.pdf. Accessed 24 Apr 2018

Fornahl D, Hassink R, Menzel MP (2015) Broadening our knowledge on cluster evolution. Eur Plan Stud 23(10):1921-1931

Frenken K, Cefis E, Stam E (2015) Industrial dynamics and clusters: a survey. Reg Stud 49(1):10-27

Fylkesmannen i Trøndelag (2019) Regionalt skog- og klimaprogram for Trøndelag, 2019-2021. Fylkesmannen i Trøndelag, Steinkjer

Goddard J, Coenen L, Kempton L, Grillitsch M, Martin R (2013) Evaluation of the cooperation between Region Värmland and Karlstad University, CURDS Newcastle University and CIRCLE Lund University. Retrieved from https:/www.kau.se/files/2019-12/Varmland\%20Evaluation\%20Report\%20FINAL\% 20VERSION.pdf. Accessed 20 May 2019

Grundel I, Dahlström M (2016) A quadruple and quintuple helix approach to regional innovation systems in the transformation to a forestry-based bioeconomy. J Knowl Econ 7:963-983

Hallencreutz D (2018) Värmlands smarta specialiseringar. En kartläggning och omvärldsanalys, Kontigo https:/gransgangaren.com/2018/08/24/omvarldsanalys-varmlands-styrkeomraden/. Accessed 15 Dec 2019

Hämäläinen S, Näyhä A, Pesonen H-L (2011) Forest biorefineries - a business opportunity for the Finnish forest cluster. J Clean Prod 19:1884-1891

Hankeraportti (2018) Euroopan aluekehitysrahasto (EAKR), Alueelliset innovaatiot ja kokeilut (AIKO), Keski-Suomen Kehittämisrahasto. Keski-Suomen liitto, Jyväskylä. Project report 2018. European Regional Development Fund, Regional innovation and experiments, Central Finland's Development Fund. Regional Council of Central Finland, Jyväskylä

Hansen T, Coenen L (2017) Unpacking resource mobilisation by incumbents for biorefineries: the role of micro-level factors for technological innovation system weaknesses. Tech Anal Strat Manag 29:500-513

Heikkinen V-P (2007) Jyväskylän seudun osaamiskeskusohjelma 2007-2013. Jyväskylä Innovation / Osaamiskeskusohjelma, PowerPoint presentation, 26 June 2007, Jyväskylä Centre of Expertise Programme 2007-2013

Henriksson J (2016) Case study report Värmland, Sweden. Mapping of EU member states' / regions' research and innovation plans \& strategies for smart specialisation (RIS3) on bio economy. RTD/F1/PP-036812015

Hermans F (2018) The potential contribution of transition theory to the analysis of bioclusters and their role in the transition to a bioeconomy. Biofuels Bioprod Biorefin 12:282-293

Hermelin B, Rämö H (2017) Intermediary activities and agendas of regional cleantech networks in Sweden. Environ Plann C Gov Policy 35(1):130-146 
Hielkema H, Hongisto P (2013) Developing the Helsinki smart city: the role of competitions for open data applications. J Knowl Econ 4(2):190-204

Hodson M, Marvin S, Bulkeley H (2013) The intermediary organisation of low carbon cities: a comparative analysis of transitions in Greater London and Greater Manchester. Urban Stud 50(7):1403-1422

Hoffman AJ (1999) Institutional evolution and change: environmentalism and the U.S. chemical industry. Acad Manag J 42:351-371

Howells J (2006) Intermediation and the role of intermediaries in innovation. Res Policy 35:715-728

Hyysalo S, Juntunen JK, Martiskainen M (2018) Energy Internet forums as acceleration phase transition intermediaries. Res Policy 47(5):872-885

Jolly S, Grillitsch M, Hansen T (2020) Agency and actors in regional industrial path development. A framework and longitudinal analysis. Geoforum 111:176-188

Kanda W, del Rio P, Hjelm O, Bienkowska D (2019) A technological innovation systems approach to analyse the roles of intermediaries in eco-innovation. J Clean Prod 227:1136-1148

Kanda W, Kuisma M, Kivimaa P, Hjelm O (2020) Conceptualising the systemic activities of intermediaries in sustainability transitions. Environ Innov Soc Trans. 36:449-465. https://doi.org/10.1016/j.eist.2020.01.002

Kangas H-L, Lintunen J, Pohjola J, Hetemaki L, Uusivuori J (2011) Investments into forest biorefineries under different price and policy structures. Energy Econ 33:1165-1176

Kanger L, Schot J (2016) User-made immobilities: a transitions perspective. Mobilities 11:598-613

Kant M, Kanda W (2019) Innovation intermediaries: what does it take to survive over time? J Clean Prod 229: 911-930

Karltorp K, Sandén BA (2012) Explaining regime destabilisation in the pulp and paper industry. Environ Innov Soc Trans 2:66-81

Kaupallistamista ja kansainvälisyyttä huippututkimusta unohtamatta (2016) SHOK-johtoryhmän suositukset yksityisen ja julkisen sektorin strategiselle yhteistyölle osaamisen ja innovaatioiden edistämisessä. Teknologiateollisuus ry, Helsinki

Keski-Suomen maakuntaohjelma 2018-2021 Keski-Suomen liitto. Julkaisu A42, 2017: Jyväskylä. Regional programme 2018-2021. Regional Council of Central Finland. Serie A42. 2017: Jyväskylä)

Keski-Suomen maakuntasuunnitelma (2006) Pdf -dokumentti, luotu 3.2.2006. Keski-Suomen liitto. Central Finland's regional plan. Regional Council of Central-Finland

Ketels C, Memedovic O (2008) From clusters to cluster-based economic development. Int J Technol Learn Innov Dev 1(3):375-392

Kivimaa P (2014) Government-affiliated intermediary organisations as actors in system-level transitions. Res Policy 43:1370-1380

Kivimaa P, Martiskainen M (2018) Dynamics of policy change and intermediation: the arduous transition towards low-energy homes in the United Kingdom. Energy Res Soc Sci 44:83-99

Kivimaa P, Boon W, Hyysalo S, Klerkx L (2019a) Towards a typology of intermediaries in sustainability transitions: a systematic review and a research agenda. Res Policy 48:1062-1075

Kivimaa P, Hyysalo S, Boon W, Klerkx L, Martiskainen M, Schot J (2019b) Passing the baton: how intermediaries advance sustainability transitions in different phases. Environ Innov Soc Trans 31:110-125

Klerkx L, Leeuwis C (2009) Establishment and embedding of innovation brokers at different innovation system levels: insights from the Dutch agricultural sector. Technol Forecast Soc Chang 76:849-860

Klitkou A (2020) Understanding forest-based value creation in a regional context. In: Brandão M, Lazarevic D, Finnveden G (eds) Handbook of the circular economy. Edward Elgar, Cheltenham (forthcoming)

Klitkou A, Capasso M, Hansen T, Szulecka J (2019) New path development for forest-based value creation in Norway. In: Klitkou A, Fevolden AM, Capasso M (eds) From waste to value: valorisation pathways for organic waste streams in circular bioeconomies. Routledge, London, pp 73-90

Konstantynova A, Lehmann T (2017) Cluster Activities in Different Institutional Environments. Case Studies of ICT-Clusters from Austria, Germany, Ukraine and Serbia. Adm Sci 7(2):1-15

Koskenlinna M, Smedlund A, Ståhle P, Köppä L, Niinikoskil M-L, Valovirta V, Halme K, Saapunki J, Leskinen J (2005) Välittäjäorganisaatiot - moniottelijat innovaatioita edistämässä. Teknologiakatsaus 168/2005. Tekes, Helsinki

Lähteenmäki-Smith K, Halme K, Lemola T, Piirainen K, Viljamaa K, Haila K, Kotiranta A, Hjelt M, Raivio T, Polt W, Dinges M, Ploder M, Meyer S, Luukkonen T, Georghiou L (2013) "Licence to SHOK?" External evaluation of the strategic centres for science, technology and innovation. Innovation 1/2013. Ministry of Employment and the Economy, Helsinki

Langley A, Smallman C, Tsoukas H, Van de Ven AH (2013) Process studies of change in organization and management: unveiling temporality, activity, and flow. Acad Manag J 56:1-13

Laur I (2015) Cluster initiatives as intermediaries: a study of their management and stakeholders. PhD Dissertation, Linköping University, Linköping 
Laur I, Klofsten M, Bienkowska D (2012) Catching regional development dreams: a study of cluster initiatives as intermediaries. Eur Plan Stud 20:1909-1921

Lindqvist M (2012) Regional innovation monitor: regional innovation report (Northern Central Sweden). Technopolis, Brussels

Manders TN, Wieczorek AJ, Verbong GPJ (2020) Complexity, tensions, and ambiguity of intermediation in a transition context: the case of connecting mobility. Environ Innov Soc Trans 34:183-208

Markard J, Raven R, Truffer B (2012) Sustainability transitions: an emerging field of research and its prospects. Res Policy 41:955-967

Martin R, Sunley P (2011) Conceptualizing cluster evolution: beyond the life cycle model? Reg Stud 45: 1299-1318

Menzel MP, Fornahl D (2010) Cluster life cycles-dimensions and rationales of cluster evolution. Ind Corp Chang 19:205-238

Metsä Fibre (2017) Annual Review 2017. Metsä Fibre Ltd. https://www.metsafibre.com/en/Documents/ Publications/Metsa-Fibre-Annual-review-2017.pdf. Accessed 3 Oct 2018

Metsä Group plans to build a next-generation bio-product mill in Finland. Metsäliitto Cooperative, Stock Exchange Release, 23.4.2014

Metsä Group (2012) Sustainability report 2012. Metsä Group. Espoo. https://www.metsagroup.com/en/ Documents/Sustainability/Metsa-Group-Sustainability-Report-2012.pdf\#search=Sustainability\% 20report\%202012,pdf. Accessed 13 Aug 2018

Mignon I, Kanda W (2018) A typology of intermediary organizations and their impact on sustainability transition policies. Environ Innov Soc Trans 29:100-113

Mikkola N, Randall L, Hagberg A (eds) (2016) Green growth in Nordic regions - 50 ways to make it happen. Nordregio, Stockholm, p 124

Ministerråd N (2018) Nordic bioeconomy programme: 15 action points for sustainable change. Nordisk Ministerråd, Copenhagen. https://doi.org/10.6027/ANP2018-785

Nærings- og handelsdepartement (ed) (2013) Meld. St. 39 (2012-2013) Mangfold av vinnere: Næringspolitikken mot 2020, ed. Nærings- og handelsdepartement. Regjeringen Stoltenberg II, Oslo, p 184

Näyhä A, Pesonen H-L (2014) Strategic change in the forest industry towards the biorefining business. Technol Forecast Soc Chang 81:259-271

OECD (2006) Self-evaluation of the Värmland Region, Sweden. Supporting the Contribution of Higher Education Institutions to regional Development. Retrieved from https://www.oecd.org/sweden/35993157. pdf. Accessed 15 Oct 2019

Osaamiskeskusohjelma, Tuloksia ja käytäntöjä 2007-2013. Työ- ja elinkeinoministeriö. 2013: Helsinki. (Centre of Expertise Programme, Results and Practises 2007-2013. Ministry of Economic and Employment. 2013: Helsinki)

Paper Province (2017) Annual report. Retrieved from https://paperprovince.com/app/uploads/2018/11/annualreport.pdf. Accessed 22 Nov 2019

Paper Province (2019) Värmland in unique collaboration with Canada to strengthen the bioeconomy. Retrieved from https://paperprovince.com/varmland-iunikt-samarbete-med-kanada-for-att-starkabioekonomin/. Accessed 16 Jan 2020

Pyka A (2017) Transformation of economic systems: the bio-economy case. In: Dabbert S, Lewandowski I, Weiss J, Pyka A (eds) Knowledge-driven developments in the bioeconomy: technological and economic perspectives. Springer, Cham, pp 3-16

Refsgaard K, Teräs J, Kull M, Oddsson G, Jóhannesson T, Kristensen I (2018) The rapidly developing Nordic bioeconomy. In: Grunfelder J, Rispling L, Norlén G (eds) State of the Nordic region 2018. Nordic Council of Ministers, Copenhagen, pp 146-159

Region Värmland (2019) Värmland smart specialisation. PowerPoint presentation. Retrieved from https:// cribe.ca/wp-content/uploads/2019/11/D1-07-Anders-O-Afternoon-Värmland-Smart-Specialization.pdf. Accessed 11 Jan 2020

Rotmans J, Kemp R, Van Asselt M (2001) More evolution than revolution: Transition Management in Public Policy. Foresight 3(1):15-31

Scordato L, Klitkou A, Tartiu VE, Coenen L (2018) Policy mixes for the sustainability transition of the pulp and paper industry in Sweden. J Clean Prod 183:1216-1227

Skatvedt KA (2019) Arena Skog initiativ fikk støtte fra. Arena Skog, EU

Skog22 - Arbeidsgruppe fiber og bioraffineri (2014) Skog22: Delrapport Arbeidsgruppe fiber og bioraffineri, 23, Skog22

Söderholm P, Lundmark R (2009) The development of forest-based biorefineries: implications for market behavior and policy. For Prod J 59:6-16 
Sölvell O (2009) Clusters - Balancing evolutionary and constructive forces. 2nd Edition. Ivory Tower, Stockholm, pp 137

Sörensson R, Jonsson A (2014) Företag inom svensk massa- och pappersindustri 2007-2012. VINNOVA, Stockholm

Sotarauta M, Suvinen N (2019) Place leadership and the challenge of transformation: policy platforms and innovation ecosystems in promotion of green growth. Eur Plan Stud 27(9):1748-1767

Spatial Foresight, SWECO, ÖIR, t33, Nordregio, Berman Group, Infyde (2017) Bioeconomy development in EU regions. Mapping of EU Member States'/regions' research and innovation plans \& strategies for smart specialisation (RIS3) on bioeconomy for 2014-2020

Suomen metsäklusteriin on perustettu huippututkimusta verkottava innovaatioyritys, Tiedotteet (2007) Metsäteollisuus. https://www.metsateollisuus.fi/tiedotteet/suomen-metsaklusteriin-on-perustettuhuippututkimusta-verkottava-innovaatioyritys. Accessed 23 Apr 2018. (The innovation company to network expertise research has been established in Finland's Forest cluster. News 11.4.2009- Forest industry)

Suvinen N, Kolehmainen J, Nieminen M (2010) How necessary are intermediary organizations in the commercialization of research? Eur Plan Stud 18:1365-1389

Trippl M, Grillitsch M, Isaksen A, Sinozic T (2015) Perspectives on cluster evolution: critical review and future research issues. Eur Plan Stud 23:2028-2044

Trøndelag County Authority (2017) Value creation in Trøndelag: Strategi for innovation og value creation. Trondheim City Council, Trondheim

UPM (2019) Our Biofore strategy in action. UPM. https://www.upm.com/responsibility/fundamentals/Ourresponsibility-targets. Accessed 14 Oct 2019

Van Boxstael A, Meijer LLJ, Huijben JCCM, Romme AGL (2020) Intermediating the energy transition across spatial boundaries: cases of Sweden and Spain. Environ Innov Soc Trans 36:466-484. https://doi.org/10. 1016/j.eist.2020.02.007

Van Lente H, Hekkert M, Smits REHM, Van Waveren B (2003) Roles of systemic intermediaries in tranisition processes. Int J Innov Manag 7:1-33

Van Lente H, Hekkert M, Smits R, Van Waveren B (2011) Systemic intermediaries and transition processes. In: Guy S, Marvin S, Medd W, Moss T (eds) Shaping urban infrastructures: intermediaries and the governance of socio-technical networks. EarthScan, London, pp 36-52

Van Lente H, Boon WPC, Klerkx L (2020) Positioning of systemic intermediaries in sustainability transitions: between storylines and speech acts. Environ Innov Soc Trans. 36:485-497. https://doi.org/10.1016/j.eist. 2020.02.006

Van Veelen B (2019) Caught in the middle? Creating and contesting intermediary spaces in low-carbon transitions. Environ Plann C Polit Space 38:116-133. https://doi.org/10.1177/2399654419856020

Van Vught F, Garlick S, Nordström L, Yelland R (2006) Supporting the contribution of higher education institutions to regional development. Peer Review Report: Värmland Region Sweden Paris: OECD

Van Welie MJ, Boon WPC, Truffer B (2020) Innovation system formation in international development cooperation: the role of intermediaries in urban sanitation. Sci Public Policy 47:333-347. https://doi.org/ 10.1093/scipol/scaa015

Venn L (2015) Fra skog til fiber, energi og bygg. Norsk Skogbruk, In, pp 30-33

Vilhula A, Kosonen K-J, Sotarauta M (2006) Yliopistot ja osaamiskeskusohjelmat aluekehittämisessä. SENTE -julkaisu 21/2006. Alueellisen kehittämisen tutkimusyksikkö. Tampereen yliopisto, Tampere

Vision Hunters (2018) This is Plänet B. Summary of PlänetB project 28.6.2018. Vision Hunters, PowerPoint presentation

Wallin J, Laxell P (2013) Alueet globaaleissa ekosysteemeissä. Osaamiskeskusohjelman loppuarviointi. Työja elinkeinominiteriön julkaisuja 19/2013: Työ- ja elinkeinominiteriö, Helsinki 